\title{
DETERMINATION OF LAND SUITABILITY USING MULTI CRITERIA APPROACH: A CASE STUDY OF BHILWARA DISTRICT RAJASTHAN
}

\author{
Naha Pandey and Chilka Sharma \\ School of Earth Science, Banasthali Vidyapith, Niwai, (Rajasthan) India \\ Email: pandeyneha2014@gmail.com, chilkasharma@gmail.com
}

\begin{abstract}
Land is one of the most important natural resource which facilitates the physical basis of various kinds of activities and natural process like habitations, agriculture, recreation etc. Every type of land and every piece are suitable for some kind of utilization depending upon their capabilities, potential and suitability for various uses. Methods and types of decisions for utilization must be on its suitability for different purposes. Now a days land resources are being used without assessing/ determining capabilities of land and optimum method of utilization like marginal land \& unproductive land are being utilized for cropping, good fertile agricultural lands are being engulfed by settlements, industries, construction of roads etc. As a result large areas are losing their productivity and are converted into degraded wasteland. The purpose of the study is to determine the land suitability analysis through Remote Sensing \& Geographical Information Systems (GIS) technology (By assessing parameters like slope, geomorphology and land-use/land-cover) in which decision rules are applied on the multi-criteria basis. Decision rules are used for the categorization of lands for various purposes like intensive agriculture, rainfed agriculture recreation, horticulture, pasture development, forest plantation, Settlement etc. The present research is an attempt to analyse suitability of land resources of Bhilwara district of Rajasthan state and suggests optimum utilization for various purposes through integration of various thematic layers, present utilization carrying capacity of land in framework of multi-criteria decision rule and also suggested optimum purposes of utilization for each piece of land in Bhilwara district.
\end{abstract}

Key words: Agriculture, Land Suitability, Remote Sensing \& GIS, Multi-Criteria Decision Rule

\section{Introduction}

Land is considered to be the most important component of earth system and evaluation of land plays major role for agriculture and other human activities of production and its classification acts as an important tool for its better use. Proper use of land depends on the suitability or utilization of land. Land suitability analysis is needed for various purposes. It reduces the human influence on natural resources. Land resource inventories are used to determine land suitability which becomes a standard part of planning process at different levels. In India agriculture is one of the major economic activities in which two-third of Indian's population is engaged. Due to over exploitation and mismanagement land is being degraded specifically when land is utilized for the purpose it is not suitable. This problem of land degradation can be managed through land suitability analysis and land should be utilized for the purpose, it is utilized. All the land is classified as per their suitability depending upon various parameters such as physical and chemical properties of soil, slope, present use etc. Our study focused on proper utilization and management of land at field level which is very much essential for farmers. Multi-criteria approaches have been applied for the land suitability analysis of Bhilwara district. Remote sensing and GIS technology is being used to monitor agriculture and crop growth status in term of both space and time (Jeyaseelan 2003; Seelan et al. 2003). It provides facility to the user for detecting the changes on the Earth's surface at different scales. Whereas specific characteristics of remotely sensed data like; large area coverage, good spatial resolution, accessibility to remote areas and faster interpretation with higher degree of objectivity and reproducibility made remote sensing becoming progressively important for mapping land use and land cover (Ibrahim M.S, et.al. 2013). The use of land is not only determined by the user but also by its suitability. 


\section{Study Area}

Bhilwara district is located in south eastern part of Rajasthan state. The coordinates of this district are $25^{\circ} 00^{\prime} 38.87$ to $25^{\circ} 57^{\prime} 53.70$ North latitude and $74^{\circ} 00^{\prime} 31.67$ to $75^{\circ} 27^{\prime} 46.25$ east longitude. The total geographical area of the district is $10,455 \mathrm{sq} \mathrm{km}$. According to the 2011 census Bhilwara district has a population of 2,408,523 of which male and female were $1,220,736$ and 1,187,787 respectively. It is bounded in the north by Ajmer district in the northwest, west and south-west by Rajsamand district; in the south and south-east by Chittaurgarh district and in the east and north-east by Bundi and Tonk district. The mostly area of district is covered by gently slope except in western \& northwestern part where slope is high. Fig. 1. shows the geographical extent of study area.

Figure 01: Geographical Extent of Study Area

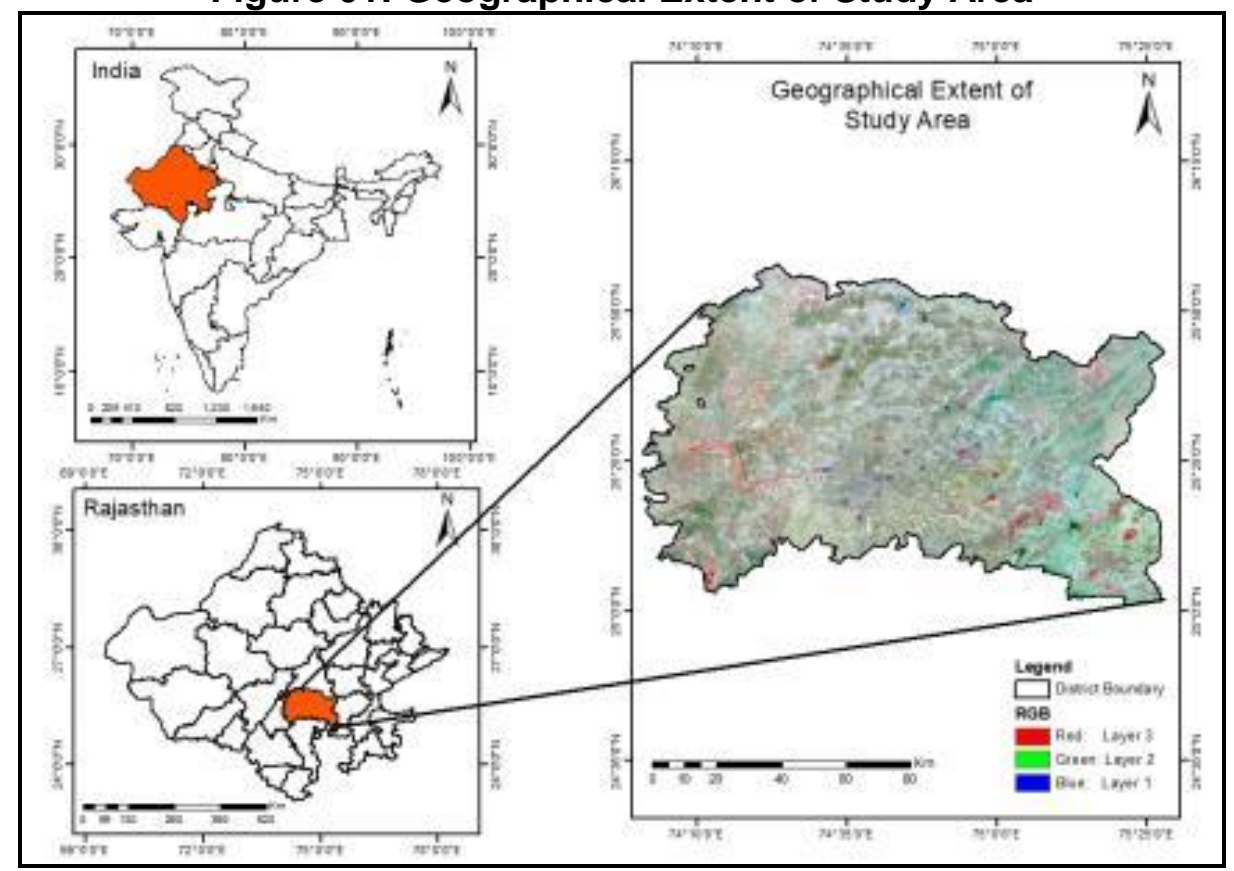

Many seasonal rivers such as Kothari, Banas, Menali, Bedach, Khari and Mansi meander their way through Bhilwara district of Rajasthan. The district falls in the Banas (9157.2 sq km), Chambal (1164.9 sq.km) \& Luni basins (133.0 sq.km) (CGWB report- 2013). Banas is the major river of the district which flows towards east direction and its tributaries are Bedach, Kothari \& Khari. The highest amount of water is received by the rainfall which is the most important factor for agriculture, industry and domestic purpose. Figure 2 shows that study area has good network of drainage, road and railway.

Figure 02: Base Map of Bhilwara district

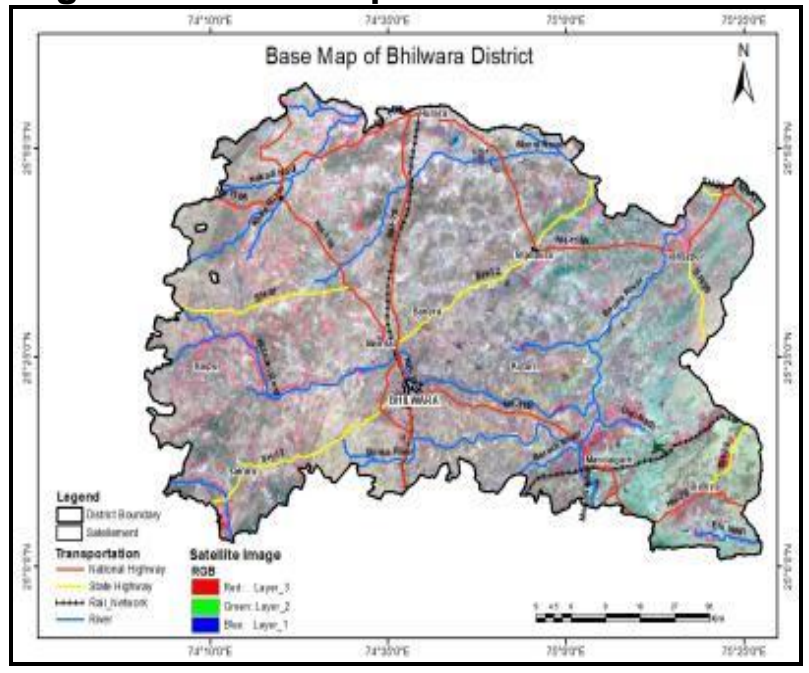

Figure 03: Integrated LU/LC Map

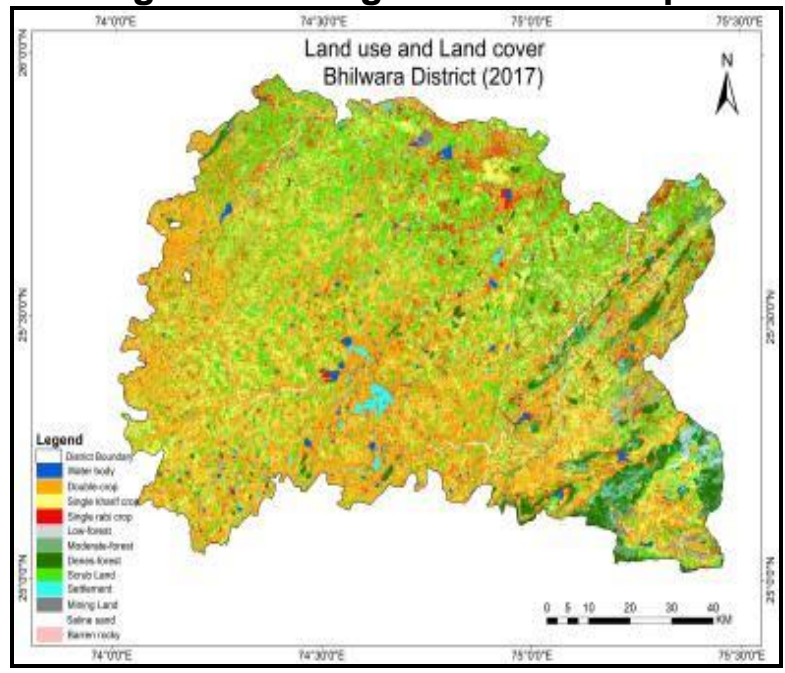




\section{Data Used}

In the research, Landsat 8 satellite data for the period of 2017 for both Rabi season (23rd -30th November, 2017) and kharif season (20th-27th September, 2017) data was downloaded from https://www.usgs.gov./. Abstraction of slope has been done from DEM (30m). Administrative map were collected from Survey of India. Geo-morphology map is collected from Geological Survey of India.

\section{Remote Sensing \& GIS Analysis}

Landsat-8 satellite image of the year 2017 is used to calculate the land-use/land-cover of entire district. There are total 11 Lulc classes categorizes in which crops are categorized in three classes i.e., double crop, Single rabi crop \& single kharif crop and forest is also classified in three classes i.e., dense forest, degraded forest \& open forest and remaining classes waterbody, built-up, scrubland, saline, barren rocky and mining/ dump areas which are done through the unsupervised classification in ERDAS 2014. LULC map is presented in Figure 3. By applying unsupervised classification on both Rabi \& Kharif satellite data and further classified this information classify into two classes, crop \& non-crop for both the seasons. Further these two classes were converted from raster to vector data and then intersected both vector layers using ArcGIS 10.4. Through which 3 classes of crops are derived i.e, double crop, single Rabi \& single Kharif crop. Thereafter we observed four combinations which are given below:

Kharif crop x Rabi crop = Double crop.

Kharif crop x Rabi-non-crop = Single Kharif.

Rabi crop x Kharif-non-crop = Single Rabi. Kharif-non-crop $\times$ Rabi-non-crop = Non-crop.

By applying Normalized Difference Vegetation Index (NDVI) forest are classified into three categories i.e. dense forest, degraded forest \& open forest.

Table 01: Area of Land use and Land Cover

\begin{tabular}{|c|l|c|}
\hline$\#$ & Landuse/Landcover Classes & Area in Percent \\
\hline 1 & Water Body & 01.15 \\
\hline 2 & Scrub Land & 28.33 \\
\hline 3 & Settlements & 1.23 \\
\hline 4 & Mining & 0.66 \\
\hline 5 & Saline Land & 2.71 \\
\hline 6 & Barren rocky & 0.62 \\
\hline 7 & Dense Forest & 3.24 \\
\hline 8 & Degraded Forest & 1.16 \\
\hline 9 & Open Forest & 0.88 \\
\hline 10 & Double-crop & 26.48 \\
\hline 11 & Single kharif crop & 23.30 \\
\hline 12 & Single rabi crop & 10.25 \\
\hline
\end{tabular}

\section{Thematic Mapping and Database Generation}

Various thematic maps such as lulc Geomorphology map \& slope map were also prepared in ArcGIS 10.4. Digitizing is the process of converting features on a paper map into digital format. Slope map is generated using SRTM 90m DEM data. Slope was further classified in 3 classes i.e. Gentle Slope, Moderate Slope \& Steep Slope as presented in table 2.

Table 02: Percentage of Area under Each Slope Category

\begin{tabular}{|c|c|c|c|}
\hline$\#$ & Slope Types & Slope in Degree & Area in Percent \\
\hline 1 & Gentle Slope & $0-3$ & 92.11 \\
\hline 2 & Moderate Slope & $3-5$ & 4.5 \\
\hline 3 & Steep Slope & $5+$ & 3.39 \\
\hline
\end{tabular}

The earth's surface can be classfied into different geromorphic units/landforms based on their physiographic expression, origin, material contant and climatic condition, etc. Geomorphology map is collected from Geological survey of India (GSI) and digitized in ArcGIS 10.4. Major geomorphic units of Bhilwara district are flood plain along rivers'-Khari, Masi, Banas, and Kothari, Valley Fill occurs in Small scattered patches in east \& west, Pediment 
Scattered in entire district, mainly in east \& west parts. Denudation hills plateau and pediments are found across the entire district (Fig.5).

Figure 04: Slope Map of Bhilwara District.

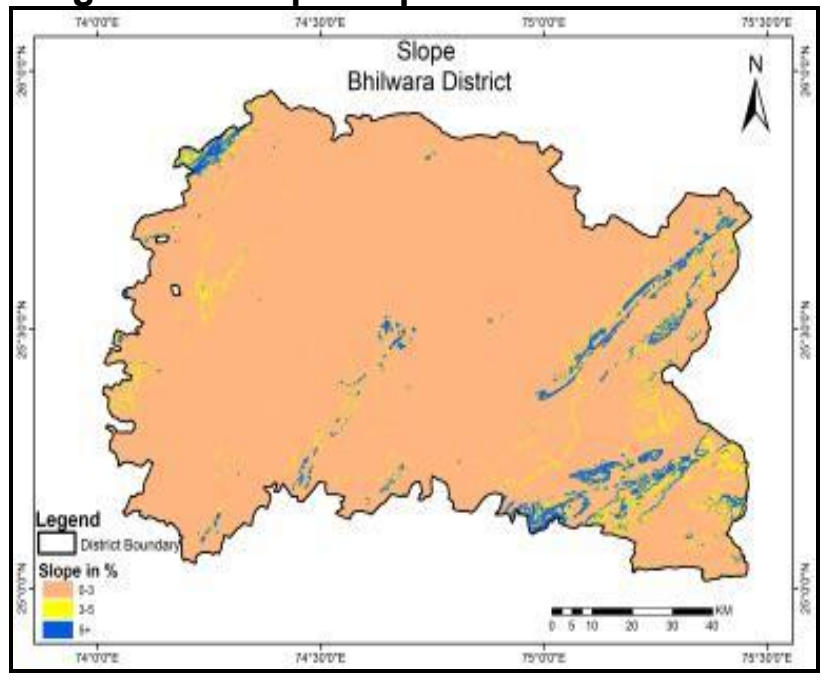

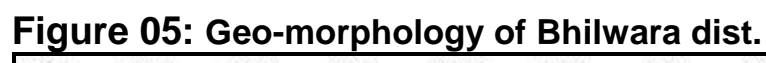

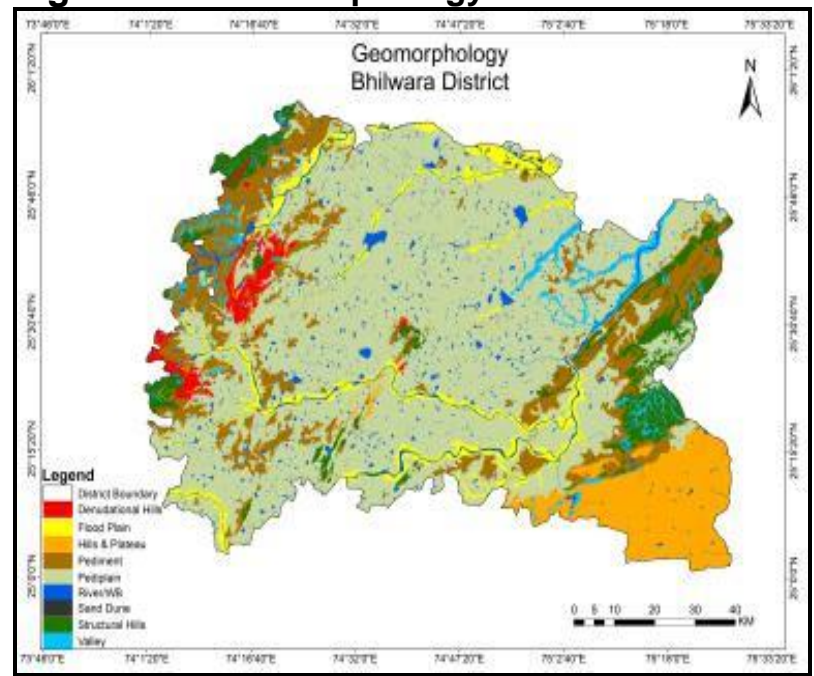

\section{Decision Making for Land Suitability}

Overlay analysis is used to identify the suitable area for the intensive agriculture, rainfed agriculture, pasture development, Horticulture development, forest plantation and Settlement. Land use, geo-morphology \& slope layers are integrated and a decision rule for land suitability is prepared for various land utilization by taken multi-criteria analysis, presented in table 3 . This study facilitates the farmer's decision makers to identify the suitable area for various purposes.

\section{Result Discussion}

Land suitability classification is the first and most essential task to be taken for the sustainable use of land. In the study, multi-criteria decision rule is developed on basis of three layers i.e., lulc, geo-morphology, slope and their different classes (table 3) by applying intersect method using Spatial Analyst tools in ArcGIS 10.4. Multi-criteria decision rules are applied for identification of land suitability for the various purposes which are intensive agriculture, rainfed agriculture, recreation, horticulture, pasture development, forest plantation.

Table 03: Multi-Criteria Decision Rules for Suitability Analysis

\begin{tabular}{|l|l|l|l|}
\hline Classes & Lulc & Geomorphology & Slope \\
\hline Intensive Agriculture & Double \& Single rabi crop & $\begin{array}{l}\text { Padiplain, Flood Plain \& Valley } \\
\text { Fill }\end{array}$ & $0-3$ degree \\
\hline Rainfed Agriculture & $\begin{array}{l}\text { Single Rabi, Single Kharif \& } \\
\text { Scrubland }\end{array}$ & $\begin{array}{l}\text { Pediment, Flood Plain \& } \\
\text { Padiplain }\end{array}$ & $\begin{array}{l}0-3 \& 3-5 \\
\text { degree }\end{array}$ \\
\hline $\begin{array}{l}\text { Horticulture } \\
\text { Development }\end{array}$ & $\begin{array}{l}\text { Single Kharif, Scrubland \& saline } \\
\text { land }\end{array}$ & Flood Plain \& Pediment & $\begin{array}{l}0-3 \& 3-5 \\
\text { degree }\end{array}$ \\
\hline Pasture Development & Scrubland \& saline land & $\begin{array}{l}\text { Denudational Hills, Pediment \& } \\
\text { Sandunes }\end{array}$ & $\begin{array}{l}5+ \\
\text { degree }\end{array}$ \\
\hline Settlement & $\begin{array}{l}\text { Scrub land\& settlement with 5 km } \\
\text { buffer }\end{array}$ & $\begin{array}{l}\text { any } \\
\text { Geo-Morphology }\end{array}$ & $\begin{array}{l}0-3 \text { \& 3-5 } \\
\text { degree }\end{array}$ \\
\hline Forest Plantation & Degraded forest & $\begin{array}{l}\text { any } \\
\text { Geo-Morphology }\end{array}$ & any slope \\
\hline Recreation & Water bodies \& Barren rocky & $\begin{array}{l}\text { Structural Hills, Denotational } \\
\text { Hills \& Waterbodies }\end{array}$ & $\begin{array}{l}5+ \\
\text { degree }\end{array}$ \\
\hline
\end{tabular}

Decision rule have been developed for different land utilization which are as follows:
a) Decision Rule for Intensive Agriculture.
b) Decision Rule for Horticulture Development.
c) Decision Rule for Rainfed Agriculture.
d) Decision Rule for forest-plantation.
e) Decision Rule for Pasture development.
f) Decision Rule for settlement.

For preparing these rules we considered different lulc classes which were intersected with layer of geomorphology and layer of slope. The Land suitability map for different parameters discussed above is shown in Figure 6. 
Area found suitable for intensive agriculture is already being used almost optimally except few areas under single Rabi crop can be converted into double cropping with suitable irrigation. This area is mainly confined to central and south-western part of district especially in Sahara, Suwana and total portably of Bhilwara district.

Figure 06: Intensive Agriculture

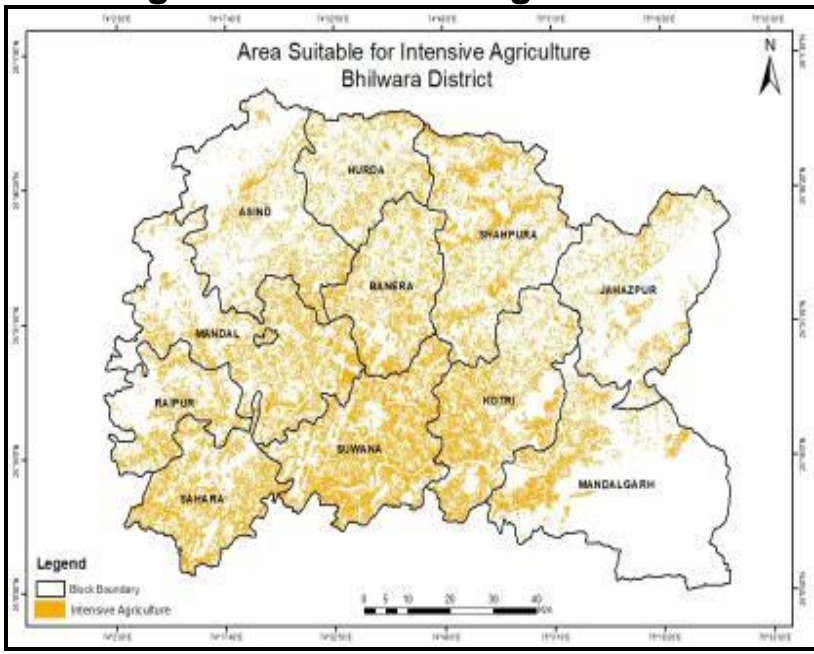

Figure 07: Pasture Development

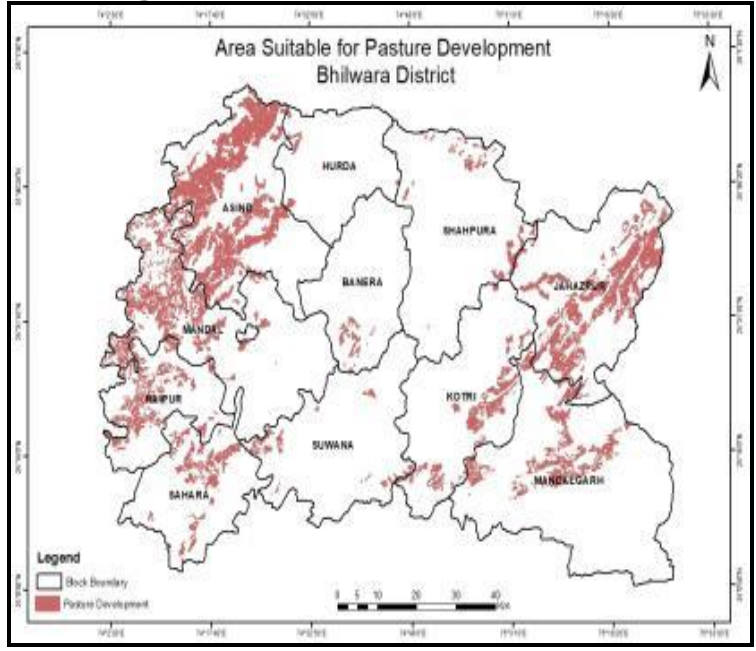

Decision rule for Intensive Agriculture $=$ Double crop \& Single Rabi crop $\cap$ Pedi plain, Flood Plain \& Valley fill $\cap$ Plain area (slope $0-3$ degree)

Pasture Development $=$ Scrubland \& saline land. $\cap$ Denudational hills, Pediment $\&$ sandunes $\cap$ Steep slope (above 5 degree).

Low altitude of denudation hills and moderate to steep slope with small soil cover are found for suitable for pasture development in north-western \& north-eastern part of Bhilwara district. $514.69 \mathrm{sq}$. km. (4.92 percent) of total area Bhilwara district is suitable for pasture development.

More than 50 percent of area suitability for rainfed agriculture which is kharif crop specially concentration in northern blocks like Banera, Hurda, Shahpura and Asind block. 5273.78 sq. $\mathrm{km}$. (50.44 percent) area of total area of Bhilwara district is suitable for rainfed agriculture.

Figure 08: Rainfed Agriculture

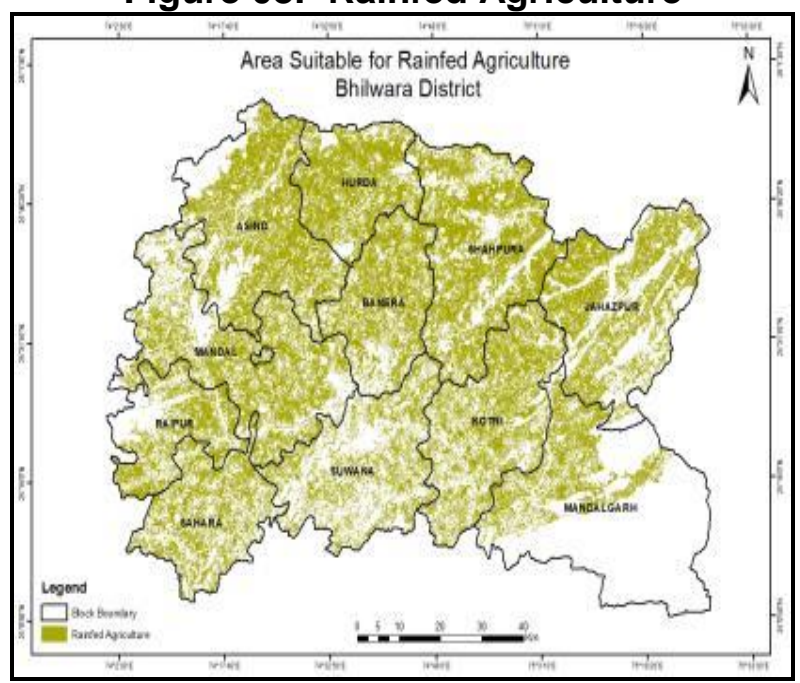

Figure 09: Horticulture Development

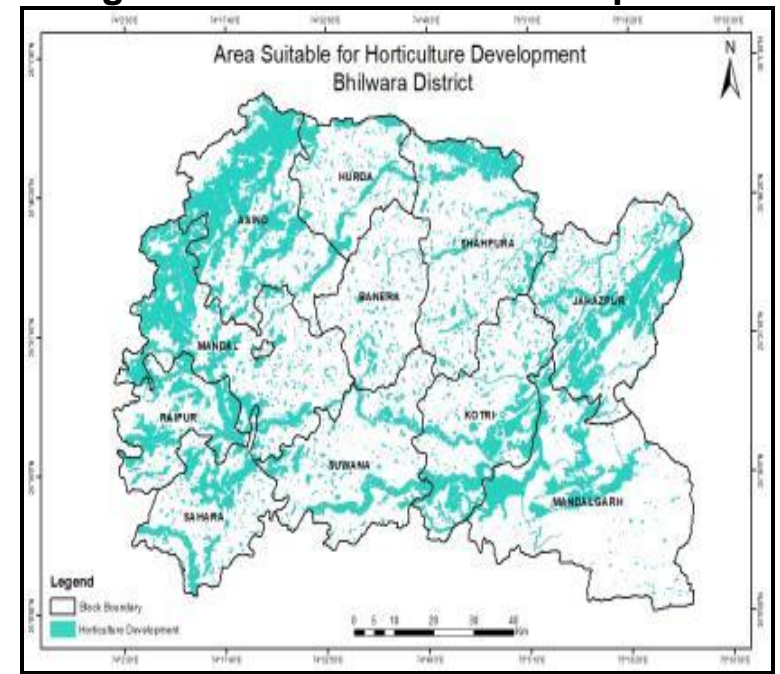

Rainfed Agriculture $=$ Single kharif, single Rabi crop \& scrubland $\cap$ Pedi plain, Flood Plain \& Pediment $\cap$ Plain area \& moderate slope (0-3 \& 3-5 degree).

Horticulture Development $=$ Single kharif crop, scrubland \& saline land. $\cap$ Pediment and flood plain $\cap$ Plain \& moderate slope (0-3 \& 3-5 degree). 
Area of foothill having slight and moderate slope up to 5 degree and having soil cover is found suitable for horticulture plantation. Such area is found along the hills in Asind, Jahazpur, Mandal, Raipur and portable blocks of Bhilwara district. $1286.23 \mathrm{sq}$. km. (12.30 percent) of total area Bhilwara district is suitable for horticulture development.

Figure 10: Forest Plantation

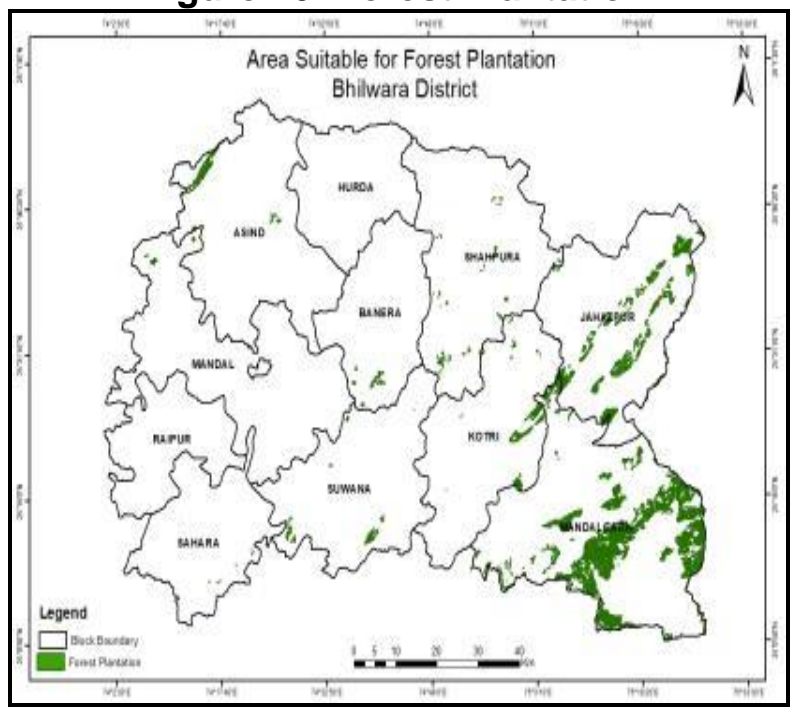

Figure 11: Recreation Land

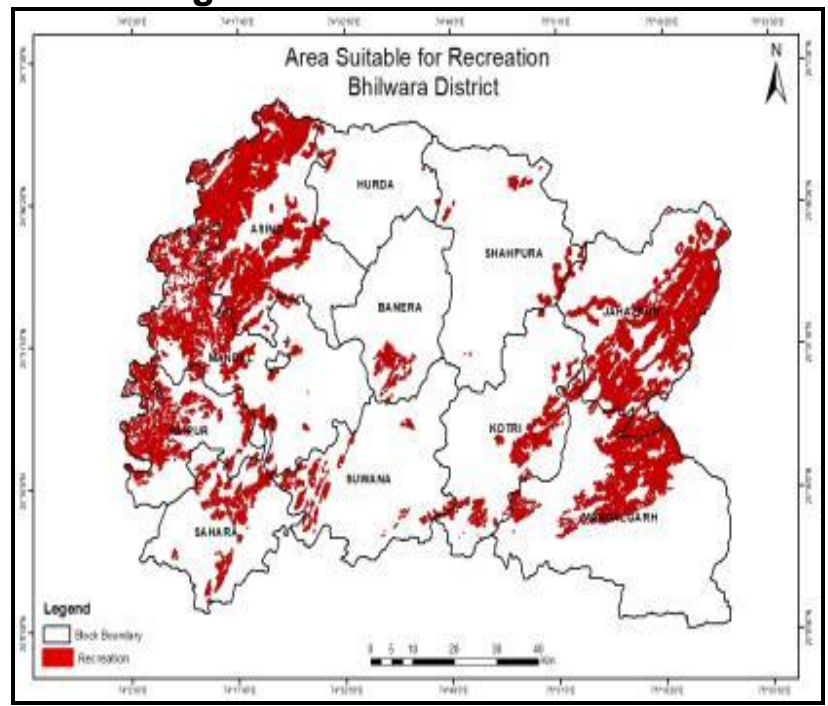

Forest Plantation $=$ Degraded forest $\cap$ Any Geo-morphology $\cap$ Any slope.

Recreation $=$ Water bodies $\&$ barren rocky $\cap$ denudation hills, structural hills \& water bodies $\cap$ Steep slope (above 5 degree).

All degraded forest areas a must be covered for forest plantation specially Mandalgarh \& Jahazpur blocks. 119.42 sq. km. (1.14 percent) of total area Bhilwara district is suitable for pasture development. $716.81 \mathrm{sq}$. km. (6.86 percent) area of total area of Bhilwara district is suitable for rainfed agriculture.

Area surrounding to the settlement with little slope and under any land-use categories are suitable for expansion of habitation. $402.88 \mathrm{sq}$. km. (3.85 percent) of total area Bhilwara district is suitable for pasture development.

Figure 12: Settlement

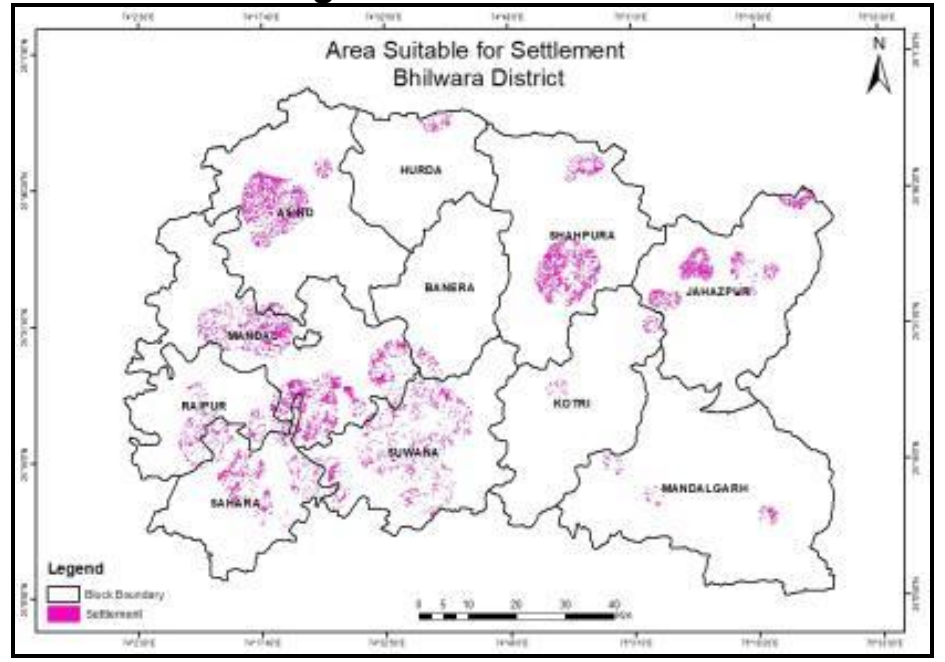

Settlement $=$ Scrub land \& settlement $5 \mathrm{~km}$ buffer $\cap$ Any Geo-morphology $\cap$ Plain \& moderate slope $(0-3$ \& 3-5 degree). 
Table 03: Area Suitable for Optimum Utilization of Land

\begin{tabular}{|c|c|c|c|c|c|c|c|c|c|}
\hline Block Name & $\begin{array}{l}\text { Area } \\
\text { Suitable } \\
\text { for } \\
\text { Intensive } \\
\text { Agriculture } \\
\text { (sq. km.) }\end{array}$ & $\begin{array}{l}\text { Total } \\
\text { Geographical } \\
\text { Area Of Block } \\
\text { in } \\
\text { (sq. km.) }\end{array}$ & $\begin{array}{l}\text { Total Area } \\
\text { of each } \\
\text { Block in \% } \\
\text { for } \\
\text { Intensive } \\
\text { Agriculture }\end{array}$ & $\begin{array}{l}\text { Total Area } \\
\text { of each } \\
\text { block in \% } \\
\text { for Rainfed } \\
\text { Agriculture }\end{array}$ & $\begin{array}{l}\text { Total Area } \\
\text { of each } \\
\text { Block in \% } \\
\text { for } \\
\text { Horticulture }\end{array}$ & $\begin{array}{l}\text { Total area of } \\
\text { each Block } \\
\text { in \% for } \\
\text { Pasture } \\
\text { Land }\end{array}$ & $\begin{array}{l}\text { Total area } \\
\text { of each } \\
\text { Block in \% } \\
\text { for Forest- } \\
\text { Plantation }\end{array}$ & $\begin{array}{l}\text { Total Area of } \\
\text { each Block in } \\
\% \text { for } \\
\text { Recreation }\end{array}$ & $\begin{array}{l}\text { Total Area } \\
\text { of each } \\
\text { Block in \% } \\
\text { for } \\
\text { Settlement }\end{array}$ \\
\hline Asind & 184.03 & 1124.00 & 16.37 & 58 & 25.29 & 15.82 & 0.25 & 19 & 5.23 \\
\hline Banera & 205.52 & 669.00 & 30.72 & 64 & 2.73 & 0.86 & 0.12 & 2 & 0.64 \\
\hline Hurda & 140.80 & 609.00 & 23.12 & 72 & 9.22 & 1.12 & 1.86 & 1 & 0.78 \\
\hline Jahazpur & 141.92 & 1039.00 & 13.66 & 53 & 17.59 & 10.02 & 0.37 & 16 & 4.38 \\
\hline Kotri & 315.39 & 927.00 & 34.02 & 58 & 12.13 & 3.53 & 0.04 & 4 & 0.54 \\
\hline Mandal & 320.40 & 1214.00 & 26.39 & 50 & 14.07 & 4.90 & 5.78 & 6 & 8.28 \\
\hline Mandalgarh & 175.35 & 1545.60 & 11.34 & 20 & 8.72 & 2.83 & 0.01 & 7 & 0.52 \\
\hline Raipur & 126.76 & 520.00 & 24.38 & 49 & 18.17 & 6.02 & 0.14 & 8 & 3.86 \\
\hline Sahara & 258.84 & 636.00 & 40.70 & 54 & 11.96 & 4.25 & $\begin{array}{c}\text { not } \\
\text { available }\end{array}$ & 5 & 6.52 \\
\hline Shahpura & 305.59 & 1129.00 & 27.07 & 68 & 8.65 & 1.47 & $\begin{array}{c}\text { not } \\
\text { available }\end{array}$ & 1 & 5.07 \\
\hline Suwana & 419.75 & 932.46 & 45.02 & 42 & 6.27 & 1.01 & $\begin{array}{c}\text { not } \\
\text { available }\end{array}$ & 2 & 6.14 \\
\hline
\end{tabular}




\section{Conclusion}

Decision rule prepared for land suitability analysis for various purposes are working very well and the system is able to identify appropriate areas suitable for intensive agriculture, rainfed agriculture, horticulture development, pasture development, recreation, forest plantation etc. The result shows that every piece of land can be utilized optimally with science and technology interventions through well designed decision rules.

\section{Acknowledgement}

The authors are thankful to Birla institute of Scientific Research (BISR) Jaipur for providing the resources that enabled us to carry out this study. The assistance provided by School of Earth Sciences, Banasthali Vidyapith. The authors are also thankful to USGS for providing all the satellite images.

\section{References}

1. Panhalkar, S. (2011) Land capability classification for integrated watershed development by applying remote sensing and GIS techniques. Journal of Agricultural and Biological Science, 6(4), 46-55.

2. Raut, S., Sarma, K. S. S., \& Das, D. K. (2010) Study of irrigation and crop water requirements and growth of two Rabi crops grown in a semi arid region using a grometeorology and remote sensing. Journal of the Indian Society of Remote Sensing, 38(2), 321-331.

3. Abdel Rahman, M. A., Natarajan, A., \& Hegde, R. (2016) Assessment of land suitability and capability by integrating remote sensing and GIS for agriculture in Chamarajanagar district, Karnataka, India. The Egyptian Journal of Remote Sensing and Space Science, 19(1), 125.

4. Ambarwulan, W., Santoso, P. B., Sabiham, S., \& Hikmat, M. (2016) Remote sensing and land suitability analysis to establish local specific inputs for paddy fields in Subang, West Java. Procedia Environmental Sciences, 33, 94-107.

5. Barham, P., Dragovic, B., Fraser, K., Hand, S., Harris, T., Ho, A., \& Warfield, A. (2003, October). Xen and the art of virtualization. In ACM SIGOPS operating systems review (Vol. 37, No. 5, pp. 164-177). ACM.

6. Bhavani, P., Chakravarthi, V., Roy, P. S., Joshi, P. K., \& Chandrasekar, K. (2017) Longterm agricultural performance and climate variability for drought assessment: a regional study from Telangana and Andhra Pradesh states, India. Geomatics, Natural Hazards and Risk, 8(2), 822-840.

7. Borana, S. L., Yadav, S. K., Parihar, S. K., \& Paturkar, R. T. (2013, September). Integration of Remote Sensing \& GIS for Urban Land Use/Cover Change Analysis of the Jodhpur city. In 33rd INCA International Congress (pp. 19-21).

8. Census Report-2011, series-09 district Census Handbook Bhilwara.

9. El Baroudy, A. A., \& Moghanm, F. S. (2014). Combined use of remote sensing and GIS for degradation risk assessment in some soils of the Northern Nile Delta, Egypt. The Egyptian Journal of Remote Sensing and Space Science, 17(1), 77-85.

10. El Garouani, A., Mulla, D. J., El Garouani, S., \& Knight, J. (2017) Analysis of urban growth and sprawl from remote sensing data: Case of Fez, Morocco. International Journal of Sustainable Built Environment, 6(1), 160-169.

11. Eldrandaly, K. (2007) GIS software selection: a multicriteria decision making approach. Applied GIS, 3(5), 1-17.

12. Government of India ministry of water resources central ground water board, Bhilwara district 2013, Rajasthan.

13. Hasmadi, M., Pakhriazad, H. Z., \& Shahrin, M. F. (2017) Evaluating supervised and unsupervised techniques for land cover mapping using remote sensing data. GeografiaMalaysian Journal of Society and Space, 5(1).

14. Ibrahim, M. M. M., Dafalla, M. S., Elhag, A. M. H., \& Ibrahim, I. S. (2013) Monitoring, predicting and quantifying soil salinity, sodicity and alkalinity in Sudan, using soil techniques, remote sensing and GIS Analysis, Case study: University of Khartoum top farm. International Journal of Scientific and Research Publications, 3(3), 1-7.

15. Jamil, M., \& Sajjad, H. (2016) Deriving cropping system efficiency pattern using remote sensing and GIS: A case study of Bijnor district, India. International Journal of Advancement in Remote Sensing, GIS and Geograph, 4(2), 27-40. 
16. Jeyaseelan, A. T. (2003) Droughts \& floods assessment and monitoring using remote sensing and GIS. In Satellite remote sensing and GIS applications in agricultural meteorology (Vol. 291). Dehra Dun, India. Geneva, Switz: World Meteorol. Org.

17. Kumar, A., Sheoran, H. S., Yadav, M., \& Hooda, R. S. Geospatial Approach for Block Wise Area Estimation of Kharif Season Crops in Fatehabad district, Haryana (India).

18. Kumar, K. N., Rajeevan, M., Pai, D. S., Srivastava, A. K., \& Preethi, B. (2013) On the observed variability of monsoon droughts over India. Weather and Climate Extremes, 1, 42.

19. Lambin, E. F. (1997). Modelling and monitoring land-cover change processes in tropical regions. Progress in physical geography, 21(3), 375-393.

20. LIU, L., LI, D., \& SHAO, Z. Research on geospatial information sharing platform based on ArcGIS Server (Vol. 37, pp. 791-795) The International Archives of the Photogrammetry, Remote Sensing and Spa-tial Information Sciences.

21. Ministry of "Environment, Forest and Climate Change" Bhilwara district survey report in Gazette Notification Dated 15th January, 2016.

22. Mohapatra, S. N., Pani, P., \& Sharma, M. (2014) Rapid urban expansion and its implications on geom.: A remote sensing and GIS based study. Geography Journal, 2014.

23. Mustafa, A. A., Singh, M., Sahoo, R. N., Ahmed, N., Khanna, M., Sarangi, A., \& Mishra, A. K. (2011) Land suitability analysis for different crops: a multi criteria decision making approach using remote sensing and GIS. Researcher, 3 (12), 61-84.

24. Prasad, H. C., Bhalla, P., \& Palria, S. (2014) Site Suitability Analysis of Water Harvesting Structures Using Remote Sensing and GIS-A Case Study of Pisangan Watershed, Ajmer district, Rajasthan. The International Archives of Photogrammetry, Remote Sensing and Spatial Information Sciences, 40(8), 1471.

25. Preethi, B., \& Revadekar, J. V. (2013). Kharif foodgrain yield and daily summer monsoon precipitation over India. International Journal of Climatology, 33(8), 1978-1986.

26. Rana, R. S., \& Prakash, C. (1992). Soil quality of Bhilwara district (Rajasthan) in relation to pisciculture. Journal of the Indian Fisheries Association, 22, 83-87.

27. Rogan, J., \& Chen, D. (2004) Remote sensing technology for mapping and monitoring landcover and land-use change. Progress in planning, 61(4), 301-325.

28. Sarajlic, S. (2012) Land Cover Change and Mineral Composite Assessment of Tushka Depression, in Egypt, Using Remote Sensing and GIS.

29. Seelan, S. K., Laguette, S., Casady, G. M., \& Seielstad, G. A. (2003) Remote sensing applications for precision agriculture: A learning community approach. Remote Sensing of Environment, 88(1-2), 157-169.

30. Sehgal, K. K. (1960) Raj. District Gazetteers Bhilwara, Govt. of Rajasthan, Jaipur, 2013.

31. Singh, A., \& Sharma, A. L. (2014) Agriculturally important insect's diversity in Kharif and Rabi crops of Talwandi sabo, Punjab. International Journal of Scientific and Research Publications, 4(8), 1-5.

32. Singha, C., \& Swain, K. C. (2016) Land suitability evaluation criteria for agricultural crop selection: A review. Agricultural Reviews, 37(2).

33. Thenkabail, P. S., Enclona, E. A., Ashton, M. S., \& Van Der Meer, B. (2004) Accuracy assessments of hyperspectral waveband performance for vegetation analysis applications. Remote sensing of environment, 91(3-4), 354-376.

34. Waikar, M. L., \& Nilawar, A. P. (2014) Identification of groundwater potential zone using remote sensing and GIS technique. Int J Innov Res Sci Eng Technol, 3(5), 12163-12174.

35. Yalew, S. G., van Griensven, A., Mul, M. L., \& van der Zaag, P. (2016) Land suitability analysis for agriculture in the Abbay basin using remote sensing, GIS and AHP techniques. Modeling Earth Systems and Environment, 2(2), 101.

36. Zaitunah, A., Ahmad, A. G., \& Safitri, R. A. (2018, March). Normalized difference vegetation index (ndvi) analysis for land cover types using landsat 8 oli in besitang watershed, Indonesia. In IOP Conference Series: Earth and Environmental Science (Vol. 126, No. 1, p. 012112). IOP Publishing.

\section{Links:}

1. http://bhuvan.nrsc.gov.in/bhuvan_links.php

2. https://www.rajras.in/index.php/soils-of-rajasthan-2/

3. http://plan.rajasthan.gov.in/statistics

4. https://www.nrsc.gov.in/Careers

5. http://www.censusindia.gov.in/2011census/dchb/0824_PART_B_DCHBpercent20_BHILWARA. pdf 